\title{
Extraction And Bellier Turbidity Temperature Test (BTTT) As Tool For Identification Of Groundnut Oil From Different Seed Varietiesgrown In India
}

\author{
Dr.Shashikant Pardeshi ${ }^{1}$ \\ ${ }^{1}$ Scientific officer/Food analyst, D.P.H. L., Jalgaon \\ Email:email-sjpardeshi@gmail.com
}

\begin{abstract}
In present research work on characteristics of groundnut oil, Bellier Turbidity Temperature Test (BTTT) (acetic acid method), based on insolubility of Arachidic acid is used as a qualitative method for identification of pure groundnut oil.In this study an attempt has been made to investigate the applicability of BTTT to groundnut oils obtained from different varieties of seeds grown in different parts of India and thereby examine the influence of geographical variations on BTTT. In the present data analysis, low oil yielding groundnut seed varieties (\% oil content: 35-40) such as RSB-103-87 andRS-1exhibited BTT in the range of 39 to $39.5{ }^{\circ} \mathrm{C}$ while High oil yielding varieties (\% oil content: 44-45) such asUF70-130 and Kopargaon-1(K-1) displayed BTT in the range of $40-41^{\circ} \mathrm{C}$. The result have demonstrated the reproducibility through the analyzed data.HenceIt is observed that groundnut oil fulfils BTTT valuesas per Regulation (Food Products and Standards) 2011 of Food Safety Standards and Act 2006.The coefficient of variation is in between 0.24-0.43 in case of BTT while in case of percentage of oil yielding, it is 0.12-0.43.
\end{abstract}

Keywords: groundnut seed,oil extraction,\% oil yield, BTTT.

\section{INTRODUCTION AND OBJECTIVE}

India is the largest producer of groundnut in the world. About $88 \%$ of the groundnut area and production in India is concentrated in five states: Andhra Pradesh, Gujarat, Karnataka, Tamil Nadu, and Maharashtra. Nearly $83 \%$ of the total area is under rainy-season groundnut and the other $17 \%$ is cultivated during the post rainy season [4]. Groundnut is now grown worldwide in the tropical and temperate zones primarily as an oil seed crop [3]. India possesses varying climatic conditions results in cultivation of a wide range oil bearing crops trees and nuts. Peanuts make an important contribution to the diet in many countries. Peanut seeds are a good source of protein, lipid and fatty acids for human nutrition [10]. Groundnut/Peanut seed contains 44 to $56 \%$ oil and 22 to $30 \%$ protein on a dry seed basis and is a rich source of minerals (phosphorus, calcium. Magnesium and potassium) and vitamins $\mathrm{E}, \mathrm{K}$ and $\mathrm{B}$ group [13].The oil content of groundnut differs in quantity, the relative proportion of fatty acids, geographical location, seasons and growing conditions [1].

The quality of fats and oils is dictated by several physical such as texture, density, pacific gravity, colour, refractive index etcand chemical parameters such as acid value, iodine value, saponofication value, unsaponifable matter BTT etc are dependent on the source of oil; geographic, climatic, and agronomic variables of growth. Thus one must assess quantitatively the influence of these variables on characteristics of oils and fats; in present case on characteristics of groundnut oil,Bellier Turbidity Temperature Test (BTTT) (acetic acid method), based on insolubility of Arachidic acid is used as a qualitative method for identification of pure groundnut oil. Sometimes it is observed that groundnut oil fulfils all specifications of refined oil but fails to pass BTTT. Moreover Groundnut from different geographical locations differs in oil content.

The Bellier figure or the temperature at which turbidity appears in a specified and neutralised oil sample under specified conditions was first proposed by Bellier and modified by several workers including Franz and Adler. According to Ever in 1912, the addition of sufficient acetic acid used instated of $1 \%$ hydrochloric acid succeeding modifications in the BTT. This had been adopted by several workers and gives satisfactory results for sufficient to judge the purity of peanut oil and admixture of oils.In most cases the Bellier figure increases with the $\%$ of peanut oil in the mixture. The increase is not proportional and there is a steep rise for the $\%$ of peanut oil below $25 \%$ [11].

BTT values prescribed for the certain vegetable oils comes under the mandatory food laws in some countries but due to development towards hybridization in oil seeds, reconsideration in laws is required. The objective of the present studies was to investigate the applicability of BTTT to groundnut oils obtained from different varieties of

seeds grown in different parts of India and thereby examine the influence of geographical variations on BTTT as tool for identification of groundnut oil in reference to high oil yielding varieties of groundnut as well as low oil yielding varieties from Rajasthan and Maharashtra regions of India. 
International Journal of Research in Advent Technology, Vol.7, No.4, April 2019

E-ISSN: 2321-9637

Available online at www.ijrat.org

\section{LITERATURE REVIEW}

Barku et al., in 2012have reported changes on the chemical composition as a result of processing. However, little information on the effect of traditional processing on peanuts quality was reported. The chemical and properties of oils are amongst the most important properties that determine the quality and help to describe the present condition of oils [2].

The modified BTT test has been used by Ever for judging the purity of oils and has been found simple, rapid and fairly accurate for routine analysis as compared to the results obtained by Valenta test. Moreover, it can be conveniently used in the analysis of soap and commercial fatty acids and also for determining the $\%$ of two mixed oils. Others workers have also successfully used the same test for determining adulteration of groundnut oil in some edible oils and also suggested its analytical importance. Besides the turbidity temperatures obtained with fatty acids by the method of fryer and Weston are different from those for the respective oils, depending on the difference in the solubility of the glycerides of the oil and its fatty acids in the same solvent[6].
The solubility of oils in various solvents is a constant, depending on the nature of the glycerides composing the oil. Fryer and Weston found that a mixture of equal volume of $92 \%$ ethyl alcohol and pure amyl alcohol used as a solvent for turbidity. In Valenta test, acetic acid was used as a solvent, the results are affected by the presence of moisture in the oil and free fatty acid which lower the turbidity temperature, increasing the solubility of the oils, which raises the turbidity temperature [11].

BTT test is useful to check purity of groundnut oil. BTT values for Arachis (groundnut) oil depend on the relative insolubility of arachidic acid (C20:0) in $70 \%$ ethyl alcohol (1:2). The high BTT values of groundnut oil compared with the other vegetable oils is due to the insolubility of arachidic acid but due to the lignoceric acid (C24:0) present in the groundnut oil. They concluded that there is no direct relationship between the added lignoceric acid in groundnut oil which is responsible for the high BTT value. However, higher concentrations of lignoceric acid present in oil improve the perception of turbidity has been studied and investigated by Krishnamurthy and other workers in 1985 [9].

Table-1 Shows BTT standards/values for some edible vegetable oils under 2.2: Fats, oils and Fat emulsions as per FSSA 2006[7]

\begin{tabular}{|l|l|l|l|}
\hline Sr.no & Item no & Vegetable oil & BTT limits \\
\hline 1 & 2.2 .1 .2 & Cotton seed oil & $19.0-21.0^{\circ} \mathrm{C}$ \\
\hline 2 & 2.2 .1 .3 & Groundnut oil & $39.0-41.0^{\circ} \mathrm{C}$ \\
\hline 3 & 2.2 .1 .6 & Rape seed oil Mustard oil(toria oil) & $23.0-27.5^{0} \mathrm{C}$ \\
\hline 4 & 2.2 .1 .7 & Rape seed oil or Mustard oil-Low erucic acid & Not more than $19.0^{\circ} \mathrm{C}$ \\
\hline 5 & 2.2 .1 .8 & Virgin olive oil & $17.0^{\circ} \mathrm{C}$ Max \\
\cline { 3 - 4 } & & Refined olive oil & $17.0^{\circ} \mathrm{C}$ Max \\
\hline 6 & 2.2 .1 .10 & Safflower seed oil (barreykatel) & Not more than $16.0^{\circ} \mathrm{C}$ \\
\hline 7 & 2.2 .1 .12 & Til oil(Gingelly/sesame oil) & Not more than $22.0^{\circ} \mathrm{C}$ \\
\hline 8 & 2.2 .1 .13 & Niger seed oil (sargiyakatel) & $25.0-29.0^{\circ} \mathrm{C}$ \\
\hline 9 & 2.2 .1 .17 & Almond oil & Not more than $60.0^{\circ} \mathrm{C}$ \\
\hline
\end{tabular}

3. MATERIAL AND EXPERIMENTAL PROCEDURES

\section{$3.1 \quad$ Materials}

All the chemicals and reagents were analytical grade and used as received.four varieties of groundnut oilseeds

viz.RSB-103-87,RS-1,UF70-130 The groundnut seeds of different places were assessed for extraction of seed oil, moreover these seeds differ in oil content. Hence when one undertakes investigations on BTTT on such seeds, it is easy to investigate the influence of oil content on BTTT.All the chemicals and reagents used in present research work are analytical grades.

\section{EXPERIMENTAL PROCEDURES}

\subsection{Soxhlet Extraction Of Groundnut Seeds}

From each driedmature and healthy seedssample, $500 \mathrm{~g}$ seeds were weighed and crushed using commercial grinder. The ground mass was fed to a soxhlet extractor and equipped with thimble and
andKopargaon-1(K-1)were gathered from local market. Since these four seed varieties are used often by Oil Millers Association of Jalgaon region for expelling and filtration/ refining, the seeds were easily available for procurement. These different groundnut varieties are used in this research study. fitted with a $2 \mathrm{~L}$ round bottomed flask. Hexane was used as the extraction solvent. The extraction was carried out for a period of 8 hours. At the end of the extraction period, the solvent was recovered by using a rotary vacuum evaporator and the residual oil was dried at $75^{\circ} \mathrm{C}$ for one hour. The extract was transferred to the desiccators and then stored in air tight container until needed for further analysis[12]. The amount of groundnut oil extracted was determined as follows:Oil content $(\%)=$ (weight of oil extracted x100)/ weight of seed 


\subsection{Determination of Bellier Turbidity Temperature Acetic Acid Method}

Pipette out one $\mathrm{ml}$ of the filtered sample of oil in a flat-bottom $100 \mathrm{ml}$ round flask, add $5 \mathrm{ml}$ of $1.5 \mathrm{~N}$ alcoholic potash heating over a boiling water bath using an air condenser After complete saponification cooling, neutralised by adding carefully dilute acetic acid and then add an extra amount of $0.4 \mathrm{ml}$ of accurately measured dilute acetic acid using phenolphthalein indicator.Add 50 $\mathrm{ml}$ of $70 \%$ alcohol and mixed well.Heat and allow the flask to cool in air with frequent shaking.Note the temperature by using calibrated thermometer at which the first distinct turbidity appears which is the turbidity temperature. This turbidity temperature is confirmed by a little further cooling which results in deposition of the precipitate. Dissolve the precipitate by heating the contents to $50^{\circ} \mathrm{C}$ over water bath, again cool as desiccated above and make a triplicate determination of the turbidity temperature $[\mathbf{5 , 7 , 8}]$.

Table 2: \% Oil yield and BTT of different groundnut varieties

\begin{tabular}{|l|l|l|l|l|}
\hline \multirow{2}{*}{ Groundnut Variety } & \multicolumn{2}{l|}{ High Oil Yielding varieties } & \multicolumn{2}{l|}{ Low Oil Yielding varieties } \\
\cline { 2 - 5 } & UF70-130 Oil content & K-1 & RSB-103-87 & RS-1 \\
\hline B.T.T.*( C) & 44.19 & 44.9 & 39.81 & 36.78 \\
\hline
\end{tabular}

* Averages of three measurements

Table 3: Accuracy on \% oil content, BTTT valuesfor different varieties of Groundnut

\begin{tabular}{|l|l|l|l|l|l|l|}
\hline Groundnut Variety & \% Oil Content* & S.D & C.V. \% & BTT *0 C & S.D & C.V. \% \\
\hline UF70-130 & 44.19 & 0.06 & 0.12 & 41.0 & 0.1 & 0.24 \\
\hline K-1 & 44.9 & 0.09 & 0.2 & 40.0 & 0.17 & 0.43 \\
\hline RSB-103-87 & 39.81 & 0.1 & 0.25 & 39.0 & 0.1 & 0.26 \\
\hline RS-1 & 36.78 & 0.16 & 0.43 & 39.0 & 0.1 & 0.26 \\
\hline
\end{tabular}

* Each value is averages of three measurements, SD-standard deviation, CV-coefficient of variance

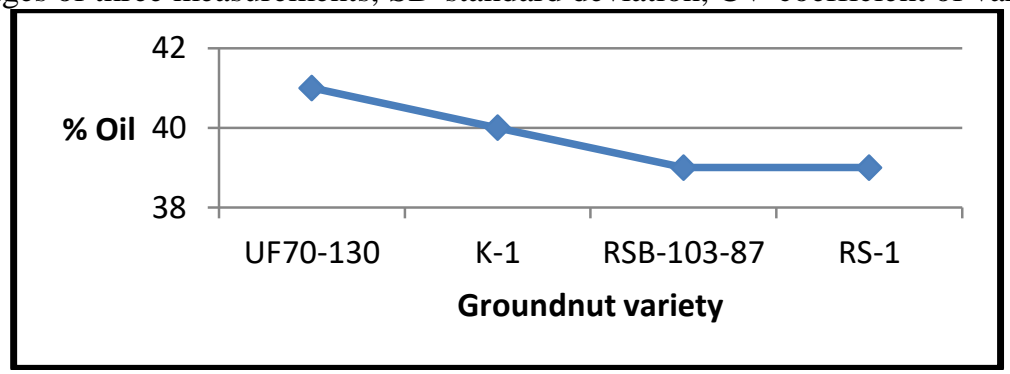

Fig. 1. shows the $\%$ oil yield of different groundnut varieties

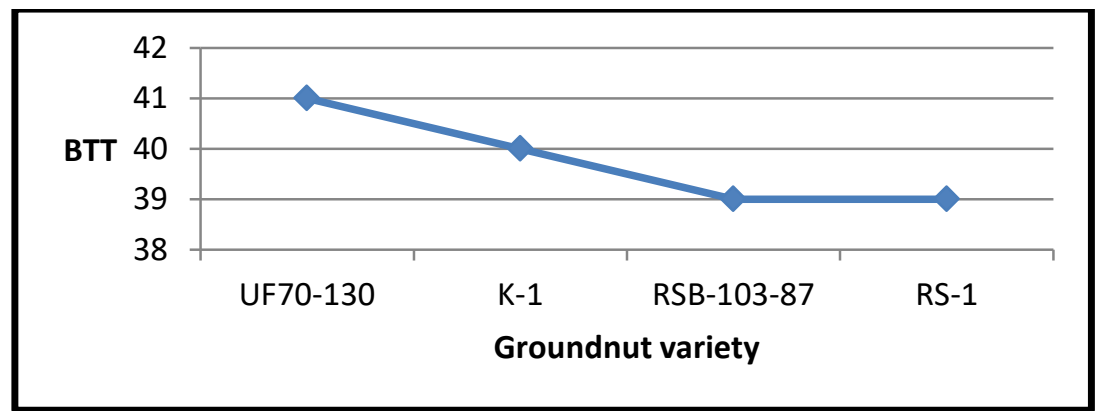

Fig.2.shows the BTTT values for different groundnut varieties

\section{RESULT AND DISCUSSION}

The results obtained for the $\%$ oil content and BTTT for the groundnut oils obtained from seven different seed varieties are shown in Table2,Fig 1and fig 2. Low oil yielding groundnut seed varieties (\% oil content: $35-40 \%$ ) such as RSB-10387 and RS-1 exhibited BTT of $39^{\circ} \mathrm{C}$. High oil yielding groundnut seed varieties (\% oil content: $44-45 \%$ ) such as UF70-130 and K-1 displayed BTT in the range of 40 to $41^{\circ} \mathrm{C}$. As all the reported BTTT values are average of three readings, the results have demonstrated the reproducibility of the analysis data. Thus the present investigations prove with due certainty the applicability of BTTT to all fourgroundnut seed varieties. Table 3 shows the accuracy, In case of $\%$ oil,RS-1, the standard deviation and coefficient is high as 0.17 and 0.43.while in case of BTT,K-1, it ishigh as 0.17 and 0.43 . 


\section{RECOMMENDATION}

Due to development towards hybridization in oil seeds, further investigations may be required to analyse the influence of seasonal variations on BTTT. Wherever required, BTTT analysis can be easily supplemented with GC and HPLC analysis, which provide the quantitative data on presence of high molecular weight fatty acids in groundnut oils.

\section{REFERENCES:-}

[1] Adeyeye et al (1992).,Adeyeye A. and Ajewole K.. Chemical Composition andFatty acid profiles of cereals in Nigeria. Food Chem. 44: 41-44.

[2] Barkuetal (2012) ,Barku V. Y. , Nyarko, H. D., \& Dordunu, P., Studies on the Physicochemical Characteristics, Microbial Load and Storage Stability of Oil from Indian Almond Nut (TerminaliaCatappal), Food Science \& Quality Management, 8. 9-17.

[3] Bansal et al (1993).,BansalUK,Satija DR, AhujaKL.,Oil composition of diver groundnut (Arachishypogaea L). Genotypes in relation to different environment. J. Sci. Food Agric., 63: 17-19

[4] CMIE (2000), India's agricultural sector: A Compendium of statistics, Bombay, India: Centre for Monitoring Indian Economy Pvt. Ltd.

[5] DGHS, (2012)., Directorate General of Health Services, Manual of methods of analysis of foods (Oils and Fats) Food Safety and Standards Authority of India (FSSAI), Ministry of health and family Welfare, Government of India, New Delhi.

[6] Desai (1947), Desai C.M.,Turbidity Temperature of oils as determines by Belier's Test and Its significance as an Analytical constant,current science 16(3), 9294.https://docslide.com.br/category/documents/ influence-of-diets-enriched-with-differentvegetable-oils-on-the -fatty-acid.html

[7] FSSA 2006 (2014).,Food safety and standards Act 2006, Rules 2008, Regulations 2011, 8th edition, Professional book publishers, New Delhi, India..

[8] I.S.I.(1984).,Indian Institution of standards, Bellier Turbidity Test, Handbook of food analysis and (part XIII) 90 .

[9] Krishnamurthy et al (1985).,M.N. Krishnamurthy ,S.Rajlaxshmi ,O.P. Kapur Influence of higher saturated fatty acids on the BTTT values of vegetable oils .,Journal of American oil chemists socoity,62(11),1606.

\section{CONCLUSION}

In this study BTTT is cheaper, easier, requires little laboratory infrastructure and recognised as a convenient qualitative tool for identification of purity of groundnut oil from different seed varieties. The present investigations prove with due certainty about applicability of BTTT to all fourgroundnut seed varieties. In particular, high oil yielding varieties were also observed to follow BTTT.This study also confirms reliability, reproducibility and diverse applicability of BTTT.

[10] Musa et al(2003).,Musa Özcan and Serap Seven., Physical and chemical analysis and fatty acid composition of peanut, peanut oil and peanut butter from ÇOM and NC-7 cultivars, Grasas y Aceites, Vol. 54. Fasc. 1,12-18

[11] Norman (1936), Norman Evers., The detection of Arachis oil in olive and almond oil,Analyst 62:96.

[12] Pearson (1981)., Pearson D.., The Chemical Analysis of Food. (8thedition). Longman Group Ltd:535.

[13] Savage et al (1994)., Savage GP, Keenan JI., The composition and nutritive value of groundnut kernels. In: Smart J. (Ed). The Groundnut Crop: Scientific basis for improvement, London: Chapman and Hall, 173-213. Springer, Netherlands. 